"Volume 10, No. 1, Juni 2016"

\title{
PEMBERDAYAAN MASYARAKAT MELALUI JAMA'AH SHOLAWATAN
}

\author{
Oleh: \\ Syarifuddin dan Samsul Arifin \\ Fakutas Syari'ah IAI Ibrahimy Situbondo \\ Fakultas Dakwah IAI Ibrahimy Situbondo \\ Syarifuddinahm@gmail.com \& goessyam@gmail.com
}

\begin{abstract}
AT-tawazun Counseling: Pesantren Based Best Practices Counselling For Developing a better person. The characteristics of Islam Nusantara (The Islamic Archipelago) which is known as tawasuth, tasamuh, and tawazun can be found in various areas of life as it covers many aspects such as thought, movement and best practices. The characteristics of Islam Nusantara are also seen in the world of psychology and counseling which have been practiced in pesantren by santri (students in pesantren) and clerics. This paper aims to; first to develop a design of psychology and counseling from the texts of classical book (kitab kuning), especially texts of morality and mysticism taught in pesantren. Second, to describe the implementation of best practices related to psychology and counseling in pesantren, especially on the formation of character psychologically so that the students (santri) grow and develop as better persons. Lastly, to understand the traces of Islam Nusantara in boarding schools (pesantren) that becomes best practices in the field of psychology and counseling.

The researcher adopted several stages of Mallon (2004: 75-85) that uses quadri-hermeneutics or reflexive methodology in one of his research as this study used qualitative research methods combined with the type of ethnographic hermeneutics. The findings are there are correlations between the quality of scientific prowess and skill (shalahiyyah) and integrity (character strength). Meanwhile, in behavior modification techniques, pesantren realm balance between the physical aspects, giving ta'zir and targhib, student-teacher mutual interaction (counselorcounselee) in the technique of application and other balance values. This at-tawazun construction is in line with the characteristics of the paradigm of thinking, social attitudes, and the context of the existence of Sukorejo Islamic Boarding School.
\end{abstract}

Key words: empowerment, advocacy, HGU 


\section{A. Pendahuluan}

Kawasan Banongan Dusun Bugeman termasuk wilayah sengketa Hak Guna Usahan (HGU) bekas hak ertpacht antara masyarakat pembuka lahan dengan PTPN Perkebunan Kapas Asembagus dan Perusda Banongan. Karena statusnya yang masih dalam sengketa itulah masyarakat hidupnya termarginalkan. Mereka kurang mendapat perhatian dari pemerintah.

Setelah kami mengadakan prelemenary research, kami menjumpai beberapa isu yang menjadi problematika masyarakat Dusun Bugeman, yaitu sengketa lahan HGU Banongan antara masyarakat dengan PTPN XXVI Perkebunan Kapas dan PG Asembagus. Menurut masyarakat, tanah Banongan tersebut dibabat pada tahun 1912. Pembukaan lahan tersebut untuk tanaman tebu sebagai pemasok Pabrik Gula (PG) milik orang Belanda. Orang Belanda tersebut berjanji nantinya tanah tersebut sebagai hak milik orang yang membabat hutan; asalkan ditanami tebu selama satu musim. Tapi pada tahun 1937, orang-orang Belanda memerintah mandor tebu untuk mengambil alih secara paksa beberapa lahan. Setelah Indonesia merdeka, lahan tersebut dikuasai PG Asembagus. Tapi masyarakat terus berjuang agar tanah tersebut menjadi miliknya.

Adapun riwayat Hak Guna Usaha (HGU) tersebut di muka adalah:

1. Recht Van Erfpacht. Verp. 170. Akte tanggal 16 Juli 1889 nomor 149, luasnya $386.3473 \mathrm{Ha}$; atas nama Guevernement Van NI (Banongan Wringin Anom I);

2. Recht Van Erfpacht. Verp. 171. Akte tanggal 16 Juli 1889 nomor 150 luasnya 289,9720 Ha; atas nama Guevernement Van NI (Banongan Wringin Anom II);

3. Recht Van Erfpacht. Verp. 171. Akte tanggal 16 Juli 1889 nomor 151 luasnya 357,6353 Ha; atas nama Guevernement Van NI (Banongan Wringin Anom III);

4. Recht Van Erfpacht. Verp. 171. Akte tanggal 16 Juli 1889 nomor 152 luasnya 281,6175 Ha; atas nama Guevernement Van NI (Banongan Wringin Anom IV);

Pada awalnya, masyarakat tidak mengetahui status tanah yang dibabatnya tersebut. Pada tahun 1992 BPN menjelaskan bahwa tanah tersebut merupakan tanah hak ertpacht; berdasarkan UU No 86 tahun 1958 terkena nasionalisasi dan menjadi tanah yang dikuasai langsung oleh Negara sejak tgl 3 Desember 1957. Tanah-tanah bekas Erfacht Banongan Verp. Nomor 170 sampai dengan 173 yang berdasarkan Undang-Undang Nomor 86 Tahun 1958 terkena nasionalisasi dan menjadi tanah yang haknya dikuasai oleh negara (HMN) sejak tanggal 5 Desember 1957, dan

22 JURNAL LISAN AL-HAL 
selanjutnya tanah tersebut diberikan kepada BUMN dan BUMD untuk dikelola dengan status Hak Guna Usaha (HGU) masing-masing sebagai berikut:

1. HGU Nomor 1 berdasarkan SK Menteri Dalam Negeri Tanggal 4 Maret 1968 Nomor : SK.12/HGU/68 atas nama PTPN XXVI (persero) perkebunan kapas, seluas 85,7170 Ha yang akan berakhir tanggal 31 Desember 1998.

2. HGU Nomor 2 berdasarkan SK Menteri Dalam Negeri Tanggal 4 Maret 1968 Nomor : SK.12/HGU/68 atas nama PTPN XXVI (persero) perkebunan kapas, seluas 64,6570 Ha yang akan berakhir tanggal 31 Desember 1998.

3. HGU Nomor 3 berdasarkan SK Menteri Dalam Negeri tanggal 14 Agustus1971 Nomor : SK.10/HGU/DA/68 atas nama Perusahaan Daerah Situbondo, seluas 330,0480 Ha yang akan berakhir tanggal 31 Desember 1998.

4. HGU Nomor 4 berdasarkan SK Menteri Dalam Negeri Tanggal 4 Juli 1972 Nomor : SK.8/HGU/DA/68 atas nama PTP XXIV-XXV Pabrik Gula Asembagus, seluas $808,7900 \mathrm{Ha}$ yang akan berakhir tanggal 31 Desember 1997.

5. HGU Nomor 5 berdasarkan SK Menteri Dalam Negeri Tanggal 14 Agustus1971 Nomor: SK.10/HGU/DA/68 atas nama Perusahaan Daerah Situbondo, seluas 37,9770 Ha yang akan berakhir tanggal 31 Desember 2011.

Mengenai lahan-lahan HGU yang diterlantarkan maka hal ini bertentangan dengan pasal 34 UUPA tentang hapusnya Hak Guna Usaha. Termasuk juga sesuai dengan SK Mendagri No. 96/1971 tentang Susunan Panitia Pemeriksaan Tanah, pasal 7.

Bagi negara-negara agraris, masalah tanah pada hakekatnya adalah masalah fundamental, seperti halnya kepemilikan tanah yang merupakan syarat mutlak bagi seorang petani. Sepanjang sejarah, sejak menusia berburu di hutan atau mengumpulkan hasil hutan, kemudian bertani mengembara sampai kepada bercocok tanam secara menetap, penguasaan dan pemanfaatan tanah seringkali menimbulkan sengketa. Kalau kita melihat kembali pada sejarah, maka tampak bahwa sengketa-sengketa itu terjadi karena tanah-tanah yang subur semakin dikuasai oleh segolongan kecil pemilik-pemilik tanah yang biasanya memiliki kekuatan politik, atau kaum "raja uang" yang merampas tanah-tanah petani bagi pengembangan industrinya ${ }^{1}$.

${ }^{1}$ Wiradi, Reforma Agraria Perjalanan Yang Belum Berakhir. (Yogyakarta: Insist, 
Sengketa agraria mampu menjadi isu sentral terutama di daerah pedesaan yang menjadi sebuah fenomena yang menarik tidak hanya terjadi di Jawa Timur, tetapi hampir tersebar banyak wilayah di negeri ini yang salah satunya adalah sengketa tanah perkebunan. Ketimpangan penguasaan dan pemilikan tanah merupakan masalah yang sangat kritis di Indonesia. Desakan liberalisasi perdagangan dengan menempatkan "tanah sebagai komoditi" membuat wilayah masalah ini semakain kompleks, di mana rakyat, terutama petani kecil diposisikan sebagai "korban" (victim) arus kapitalisme global yang nyaris tanpa jalan keluar. Persoalan sengketa tanah merupakan masalah yang rawan dan sensitif bagi rakyat, karena tanah merupakan faktor penting dalam menopang survival setiap manusia sebagai sebuah entitas. Karena itu pesoalan yang menyangkut masalah tanah perlu ditangani secara serius dan bijaksana.

Sebenarnya pendiri negara ini menyadari pentingnya masalah tanah dalam pembangunan dan potensi sengketa yang ada di dalamnya, sehingga diletakkan dasar pengaturan masalah pertanahan dalam dasar negara. Ketentuan tersebut diatur dalam Undang-Undang Dasar 1945 pasal 33 ayat (3), yang menyebutkan bahwa "Bumi, air dan kekayaan yang terkandung di dalamnya dikuasai oleh negara dan dipergunakan untuk sebesar-besarnya kemakmuran rakyat". Dari ketentuan tersebut, secara implisit terlihat bahwa bumi, air dan kekayaan alam yang terkandung di dalamnya adalah pokok-pokok kemakmuran rakyat, oleh karena itu harus dikuasai oleh negara, dengan tujuan diperuntukkan bagi kemakmuran rakyat..

Kita semua mengetahui bahwa masalah penguasaan tanah bukanlah hal yang sederhana, karena itu menyangkut bukan hanya saja hubungan manusia dengan tanah, melainkan juga (dan justru terutama) hubungan manusia dengan manusia. Seyogyanyalah kebijaksanaan agraria perlu dilandasi dengan pemahaman terhadap aspek sosial ini agar penataan kembali masalah agraria dapat dilaksanakan tanpa gejolak sosial yang destruktif ${ }^{2}$.

Sengketa pertanahan merupakan sengketa yang memiliki karakteristik yang khas, yang ditandai dengan adanya penghadapan secara vertikal fihak yang memiliki akses sumberdaya lebih lemah dengan fihak yang memiliki akses sumberdaya lebih besar atau dengan kebijaksanaan negara yang cenderung eksklusif, tidak partisipatif dan bersifat dominan

KPA dan Pustaka Pelajar, 2000), hlm. 21-22.

2 Ibid, hlm. 23.

$24 \mid$ JURNAL LISAN AL-HAL 
terhadap kontrol pendayagunaan sumberdaya.

Kebijakan perkebunan di Indonesia tidak saja melahirkan dan memperluas kantong-kantong kemiskimam (proverty enclave) dibasis perkebunan namun juga menghilangnya penguasaan dan pemilikan lahan oleh petani karena adanya berbagai bentuk perampasan tanah direjim Soeharto. Sedangkan kian besarnya angka terhadap petani dalam upaya untuk menyelamatkan aset-aset perkebunan pada era pemerintahan saat ini menunjukkan bahwa politik agraria pemerintah tidak banyak berubah dengan rejim berikutnya. Hak ini membuktikan bahwa meluasnya kemiskinan struktural tidak sekedar sebuah fakta dengan adanya pola sejarah penindasan kolonial yang mempengaruhi relasi struktur sosial ketergantungan terhadap sumber pemiskinan, mempengaruhi tingkat pendidikan petani, buruh, dan masyarakat sekitar perkebunan.

Namun juga diakibatkan tidak adanya kesungguhan dan komitmen pemerintah saat ini (political will) dalam perlindungan petani dan buruh perkebunan. Masyarakat sangat kesulitan memperoleh akses pangan yang layak, pemenuhan hak kesehatan, serta tidak adanya jaminan sosial hidup petani. Penggusuran nilai-nilai kearifan lokal dengan menggantikannya dengan nilai-nilai yang mendorong konsumtifistik-kapitalistik, dari tradisi komunalistik ke individualistik. ${ }^{3}$

Sebagai konsekuensi logis dari kebijakan-kebijakan pemerintah yang tidak populis tentang persoalan sengketa tanah perkebunan yang kompleks maka munculah radikalisme petani diberbagai kelompok sektoral dikantong-kantong konflik sengketa tanah perkebunan. Salah satu permasalahan yang kini timbul adalah maraknya perebutan tanah-tanah negara oleh masyarakat atau sering disebut reclaiming 4 .

Gerakan radikal inilah yang dinamakan reclaiming (reclaiming movement) yaitu, sebuah tindakan perlawanan rakyat tertindas untuk memperoleh hak-haknya seperti tanah, air dan sumberdaya alam serta alat-alat produksi lainnya secara adil demi terciptanya kemakmuran rakyat semesta. Gerakan reclaiming memiliki prinsip anti kekerasan serta menjaga nilai demokrasi dan HAM, sehingga dalam pelaksanaannya tidak menjadikan kaum tani menjadi tirani baru. Oleh sebab itu, gerakan reclaiming lebih mendekati pada proses keyakinan kaum tani atau komonitas kaun tertindas lainnya untuk mengembalikan atau paling tidak

3 Wijardjo, Rekleiming dan Kedaulatan Rakyat. (Jakarta: YLBHI-RACA Institute. 2001), hlm. 16.

4 Al Araf dan Awan Puryadi., Perebutan Kuasa Tanah. (LAPPERA Pustaka Utama. 2002), hlm. 77. 
memulihkan ketimpangan agraria yang menyebabkan kemelaratan dan kemiskinan di pedesaan ${ }^{5}$.

Sengketa penguasaan hak atas tanah yang terjadi di Banongan Asembagus Situbondo antara petani dengan PTPN XI, PTPN XII dan Perusahaan Daerah Banongan terjadi disebabkan salah satu faktor dari unsur kesejarahan tanah sengketa tersebut. Dimana masyarakat petani Banongan menganggap bahwa tanah tersebut sebagai hak miliknya sebagai warisan dari nenek moyang mereka dengan cara membuka (membabat) hutan.

Fenomena radikalisme petani sengketa kasus tanah perkebunan seperti yang terdiskripsikan di muka, merupakan bagian potret kasus pertanahan yang terjadi di perkebunan Banongan Asembagus Situbondo Jawa timur, yang membutuhkan perhatian serius oleh semua pihak terutama pemerintah dalam mencarikan solusi penyelesaian sengketa dan penanganannya secara tuntas.

Sebenarnya telah ada produk-produk hukum yang mengatur tentang tanah perkebunan antara lain, Undang-Undang Nomor 51 Tahun 1960 tentang Larangan Pemakaian Tanah Tanpa Ijin Pemilik atau Kuasanya yang Sah, Peraturan Menteri Pertanian Agraria Nomor 11 Tahun 1962 tentang Ketentuan-Ketentuan dan Syarat-Syarat Dalam Pemberian Hak Guna Usaha Kepada Pengusaha Swasta Nasional, Keppres Nomor 32 Tahun 1979 tentang Pokok-Pokok Kebijakan Dalam Rangka Pemberian Hak Baru Tanah Asal Konversi Hak-Hak Barat, Peraturan Menteri Dalam Negeri Nomor 3 Tahun 1979 tentang Pemberian Hak Baru Atas TanahTanah Bekas Hak Guna Usaha yang Diduduki Atau Digarap Pihak lain, serta PP Nomor 40 Tahun 1996 tentang Hak Guna Usaha, Hak Guna Bangunan dan Hak Pakai Atas Tanah.

Produk hukum yang berkaitan dengan masalah tanah perkebunan telah ada, akan tetapi sengketa masih saja muncul bahkan ada kecenderungan terjadi peningkatan. Fenomina meningkatnya eskalasi sengketa agraria ini terjadi dengan mengikuti pola kebijakan agraria dalam penyelesaian sengketa yang tersedia.

Penyelesaian sengketa tanah perkebunan menjadi semakin sulit apabila hanya mengandalkan formalitas pelembagaan penyelesaian sengketa yang tersedia selama ini. Ketidaksiapan perangkat hukum dan kebijakan publik, yang diharapkan menjadi benteng terakhir perlindungan hukum dan keadilan bagi masyarakat, menjadi permasalahan tersendiri yang memperkuat ketidak berdayaan rakyat.

\section{Perdana, 2011.}


Secara teoritis sengketa muncul ketika seseorang atau lebih yang merasa bahwa haknya talah dilanggar, akan tetapi orang yang dirasa malanggar haknya tidak mau secara sukarela melakukan atau tidak melakukan sesuatu yang diminta itu. Karena prinsipnya tidak akan ada gugatan jika tidak ada kepentingan (geen actie geen belang), dengan adanya kepentingan diantara para pihak maka salah satu pihak yang merasa telah dilanggar haknya dapat melakukan upaya hukum untuk mendapatkan haknya.

Mekanisme penyelesaian sengketa yang ada cenderung mengedepankan kebenaran formal, dan sering kali tidak menangkap kebenaran meteriil ${ }^{6}$. Di sisi yang lain lembaga peradilan dianggap tidak efektif dan efisien menyelesaikan sengketa yang banyak timbul dimasyarakat.

Prosedur yang biasa, yang dikenal dengan jalur litigasi, dalam penyelesaiaan sengketa sering kali membutuhkan waktu yang lama, biaya yang mahal, dan jaminan bahwa akan menghasilkan penyelesaian yang adil dan memuaskan para pihak yang bersengketa belum tentu dapat dicapainya. Begitu pula adanya penilaian bahwa pengadilan sulit bersikap obyektif, ketika institusi tersebut lebih berpihak pada eksekutif, sehingga kemandirian pengambilan keputusannya dipertanyakan ${ }^{7}$.

Terlepas dari sengketa tanah yang masih berlangsung tersebut, bagaimana pun kondisi masyarakat Bugeman harus diperhatikan. Berdasarkan pemikiran inilah kalangan perguruan tinggi perlu mengadakan kegiatan pengabdian masyarakat yang berbentuk dakwah pemberdayaan.

Dalam istilah Khamami Zada, dakwah pemberdayaan ini bisa disebut sebagi dakwah transformatif. Dakwah transformatif merupakan model dakwah, yang tidak hanya mengandalkan dakwah verbal (konvensional) untuk memberikan materi-materi keagamaan kepada masyarakat, yang memposisikan da'i sebagai penyebar pesan-pesan keagamaan, tetapi menginternalisasikan pesan-pesan keagamaan ke dalam kehidupan riil masyarakat dengan cara melakukan pendampingan masyarakat secara langsung. Dengan demikian, dakwah tidak hanya untuk memperkukuh aspek relijiusitas masyarakat, melainkan juga

6 Sugianto, Mekanisme Alternatif Penyelesaian Sengketa (MAPS) Dalam Sengketa Pertanahan (Suatu Pemikiran Awal Tentang Kelayakan Pengembangan MAPS Pertanahan). DIKLAT SEMA Fakultas Hukum Brawijaya Malang bekerja sama dengan Lembaga Bantuan Hukum (LBH), Surabaya. 1996, hlm. 2.

7 Mulyo, Studi Tentang Makanisme Alternatif Penyelesaian Sengketa (MAPS). (Jakarta: ELSAM. 1996), hlm. 6. 
memperkukuh basis sosial untuk mewujudkan transformasi sosial. Dengan dakwah transformatif, da'i diharapkan memiliki fungsi ganda, yakni melakukan aktivitas penyebaran materi keagamaan dan melakukan pendampingan masyarakat untuk isu-isu korupsi, lingkungan hidup, penggusuran, hak-hak perempuan, konflik antaragama, dan problem kemanusiaan lainnya.

Menurut A. Halim ${ }^{8}$, ada beberapa prinsip dalam dakwah transformatif tersebut yang perlu diperhatikan. Pertama, harus berorientasi kepada kesejahteraan lahir dan batin masyarakat. Dakwah harus direncanakan sebagai usaha membenahi kehidupan sosial bersama masyarakat agar penindasan, ketidakadilan, dan kesewenang-wenangan terkikis habis. Kedua, sebagai upaya melakukan rekayasa sosial (social engineering), untuk mendapatkan suatu perubahan tatanan kehidupan sosial yang lebih baik dengan menerapkan nilai-nilai keislaman.

Menurut Khamami ${ }^{9}$, dakwah transformatif harus memenuhi lima indikator. Pertama, dari aspek materi dakwah; ada perubahan yang berarti; dari materi ubudiyah ke materi sosial. Dalam konteks ini, para da'i sudah mulai memperkuat materi dakwahnya pada isu-isu sosial, seperti korupsi, kemiskinan, dan penindasan. Sehingga para da'i tidak lagi hanya berkutat pada materi ukhrowi. Penyebaran Islam sosial ke masyarakat secara terus-menerus melalui dakwah merupakan cara yang paling ampuh untuk mengubah pemahaman keagamaan masyarakat, bahwa beribadah bukanya secara vertikal kepada Allah, tetapi juga secara horisontal terhadap sesama manusia. Sehingga akan terjadi suatu masyarakat yang saleh individual dan saleh sosial. Ibaratnya ibadahnya rajin, kepekaan sosialnya juga tinggi, sehingga ada keharmonisan dalam beragama secara sosial.

Dari aspek materi juga ada perubahan; dari materi dakwah yang ekslusif ke inklusif. Para da'i tidak lagi menyampaikan materi dakwah yang memojokkan atau memusuhi non muslim. Kecenderungan selama ini para da'i sering menyampaikan dakwah yang bernada permusuhan terhadap agama lain. Padahal cara ini justru membuat masyarakat ikut memusuhi agama lain hanya karena agamanya yang berbeda. Karena itulah, dakwah sudah mulai diarahkan pada paradigma beragama yang toleran dan inklusif. Paradigma ini telah menjadi semangat teologi al-

8 A. Halim, Paradigma Dakwah Pengembangan Masyarakat, dalam Moh Ali Aziz (ed), Dakwah Pemberdayaan Masyarakat Paradigma Aksi Metodologi, (Yogyakarta, LKiS 2005), hlm. 15-17.

9 Khamami, Dakwah Transformatif: Mengantar Dai sebagai Pendamping Masyarakat, (www.nu.or.id 2006). 
Qur'an bahwa Islam bukanlah agama yang memusuhi umat lain, hanya karena berbeda agamanya. "Kalimatun sawa" (titik temu yang sama) antar berbagai agama yang sudah digambarkan dalam al-Qur'an menjadi kata kunci dalam dakwah transformatif.

Kedua, dari aspek metodologi terjadi perubahan; dari model monolog ke dialog. Para da'i sudah berubah cara penyampaian dakwahnya, tidak lagi menggunakan pendekatan monolog, melainkan sudah melakukan dialog langsung dengan jama'ah. Sehingga problem yang dihadapi masyarakat dapat langsung dicarikan solusinya oleh da'i dengan kemampuan yang dimilikinya. Dakwah yang menggunakan pendekatan monolog cenderung melakukan indoktrinasi kepada jamaah. Padahal, Islam tidak hanya indoktrinasi, melainkan juga pencerahan terhadap jamaah. Dakwah dengan model dialog inilah yang akan memancing keaktifan jamaah untuk berpartisipasi dalam perubahan sosial dalam dimensi keagamaan. Jika yang dilakukan hanya melulu pengajian monolog, tanpa adanya umpan balik dari jamaah, maka yang terjadi adalah sekadar menghilangan dahaga spiritual, bukan melakukan perubahan pemahaman, sikap dan perilaku sosial. Dakwah dengan model dialog dilakukan dalam rangka mencapai cita-cita dakwah transformatif.

Ketiga, menggunakan institusi yang bisa diajak bersama dalam aksi. Para da'i mesti menggunakan institusi sebagai basis gerakan agar apa yang dilakukannya mendapatkan legitimasi yang lebih kuat. Dalam kerjakerja transformasi, agenda perubahan biasanya didukung oleh basis massa atau institusi yang pada gilirannya akan digunakan sebagai perangkat kerja perubahan. Maka, dalam dakwah transformatif, institusi merupakan indikator penting untuk memuluskan jalan perubahan. Kekuatan kerja dakwah transformatif, bukan saja secara individual pada diri sang da'i, tetapi juga basis institusional yang dimilikinya, sehingga bargaining position (posisi tawar) terhadap negara, pelaku pasar, dan masyarakat bisa didapat relatif lebih mudah. Tanpa institusi yang menjadi pendukung, da'i transformatif akan kesulitan untuk melakukan aksi terhadap stakeholder-stakholder yang ada di sekitarnya.

Keempat, ada wujud keberpihakan pada mustad'afin. Para da'i terketuk hatinya untuk melakukan usaha-usaha sosial untuk kepentingan kaum tertindas di daerahnya semisal kasus penggusuran tanah, pencemaran lingkungan, nasib nelayan dan petani. Rasa empati sosial merupakan prasyarat bagi da'i yang menggunakan pendekatan transformatif. Rasa empati sosial terutama ditujukan pada si korban, baik itu korban penggusuran, korban penindasan, korban permainan ekonomi, korban konflik, dan masih banyak lagi. Empati terhadap korban menjadi 
modal dasar untuk melakukan langkah strategis untuk membantu para korban penindasan, kemiskinan, dan permainan politik.

Kelima, para da'i melakukan advokasi dan pengorganisasian masyarakat terhadap suatu kasus yang terjadi di daerahnya agar nasib para petani, nelayan, buruh, dan kaum tertindas lainnya didampingi. Inilah puncak dari para da'i yang menggunakan pendekatan transformatif. Hasil akhir dari dakwah transformatif adalah mencetak para da'i yang mampu melakukan pendampingan terhadap problem-problem sosial yang dihadapi masyaraat. Dalam konteks inilah, penyebaran dakwah di masyarakat mesti dilandasi oleh visi yang benar tentang perdamaian, kesalehan sosial, dan sesuai dengan cita-cita agama yang mendorong pada perubahan ekspresi beragama yang inklusif dan toleran. Di sinilah, para aktivis dakwah (da'i) memiliki peran yang strategis dalam merubah pandangan keagamaan masyarakat. Sebab, pemahaman keagamaan masyarakat biasanya sangat dipengaruhi oleh para da'i.

Sedangkan menurut Sarah Hlupelkile Longwe ${ }^{10}$ konsep pemberdayaan perempuan memiliki lima dimensi. Pertama, kesejahteraan. Dimensi ini merupakan tingkat kesejahteraan material rakyat yang diukur dari tercukupinya kebutuhan dasar; seperti makanan, penghasilan, perumahan, dan kesehatan. Kedua, akses. Pemberdayaan dalam hal ini berarti dipahaminya untuk mendorong rakyat melakukan tindakan untuk mengubahnya dengan cara memperoleh akses yang lebih besar terhadap sumber daya atau bahkan mampu menguasai akses tersebut.

Ketiga, kesadaran kritis. Pemberdayaan di tingkat ini, berarti penumbuhan sikap kritis dan penolakan terhadap cara pandang bahwa subordinasi terhadap perempuan bukanlah pengaturan alamiah tetapi merupakan hasil dari sistem diskriminatif dari tatanan sosial yang berlaku. Keempat, partisipasi. Pemberdayaan pada level ini adalah upaya pengorganisasian rakyat, sehingga mereka dapat berperan serta dalam setiap proses pengambilan keputusan sehingga kepentingan mereka tidak terabaikan. Kelima, kuasa. Pemberdayaan dalam tingkatan ini, merupakan upaya untuk menguatkan organisasi rakyat sehingga mereka mampu mengimbangi kekuasaan kelas atas dan mampu mewujudkan aspirasi mereka karena mereka ikut memegang kendali atas sumber daya yang ada $^{11}$.

${ }^{10}$ Sarah Hlupelkile Longwe (1991).

11 Wardah Hafidz dan Wiladi, Model Pemberdayaan Rakyat Berkeadilan Gender, dalam Panduan Pendidikan Politik Bagi Perempuan, (Komite Perempuan Pro Demokrasi, 
Fokus pemberdayaan dalam program ini adalah penguatan masyarakat untuk memperoleh kembali kuasa kelola (power of management system), kuasa milik (power of ownership system), dan kuasa manfaat (power of unility system) yang hilang. Ada dua bidang yang akan kami lakukan, yang saling berkaitan. Pertama, dalam bidang hukum. Kami akan melakukan penyadaran kepada masyarakat, agar mereka mendapatkan kembali hak-haknya. Hak-hak tersebut pada ujungnya, akan tercipta kesejahteraan masyarakat. Kedua, dalam bidang spiritual. Kami akan melakukan pendekatan dengan pendekatan keagamaan. Sebab pendekatan keagamaan ini akan lebih diterima masyarakat Dusun Bugeman.

\section{B. Metode}

Strategi yang dapat digunakan dalam melakukan pemberdayaan ini adalah dengan menggunakan pendekatan pengabdian masyarakat berbasis Participatory Rural Appraisal12. Strategi ini diharapkan data problematika masyarakat yang dijelaskan di atas (hasil studi pendahuluan) dapat ditelaah kembali, didalami bersama-sama untuk kemudian direncanakan alternatif problem solvingnya bersama masyarakat. Sehingga dapat menumbuhkan kesadaran bersama karena mereka terlibat di dalamnya, dan tim berperan hanya sebagai fasilitator.

Adapun dalam implementasinya, program ini akan dilakukan melalui beberapa cara atau metode-metode sebagai berikut:

Pertama, pengenalan situasi dan membangun restu masyarakat. Kedua, melakukan pengkajian keadaan wilayah (secara umum dan topikal), yaitu melakukan pengkajian terhadap peta wilayah, keadaan sosial-ekonomi, sosial politik, sosial budaya dan rekonstruksi sejarah masyarakat Bugeman secara umum. Setelah itu, dilanjutkan dengan melakukan kajian wilayah secara mendalam tentang problem sosial keagamaan masyarakat Bugeman dengan cara mengkaitkan problematika dan potensi wilayah di daerah tersebut. Ketiga, menyusun rencana aksi secara partisipatif bersama warga, yaitu merancang kegiatan sesuai dengan problem yang ditemukan dari hasil kajian wilayah bersama-sama dengan warga yang didasarkan atas kebutuhan mereka. Keempat, melaksanakan aksi, yaitu melakukan kegiatan atau upaya-upaya untuk

Unair Surabaya 1999), hlm. 17-19.

12 Daniel, 2006, hlm. 37-47; Sukardi, Implementasi Metodologi RRA dan PRA untuk Merancang Perubahan Berencana, dalam Moh Ali Aziz (ed), Dakwah Pemberdayaan Masyarakat Paradigma Aksi Metodologi, (Yogyakarta, LkiS, 2005), hlm. 241-247. 
memecahkan problem yang telah dikaji bersama-sama dengan warga dan dilakukan bersama-sama dengan warga pula.

Kelima, melakukan evaluasi dan refleksi, yaitu melakukan monitoring dan evaluasi atas upaya-upaya yang telah dilakukan pada aktivitas sebelumnya untuk melihat sejauhmana efekitivias dan efesiensinya. Dan bagaimana melakukan perbaikan ulang (menyusun siklus berikutnya selama masih mungkin)

\section{Pembahasan}

\section{Pengenalan Situasi}

Kabupaten Situbondo terletak di pantai utara Jawa Timur bagian timur, kurang lebih 7-35 dan 7-44 di sebelah selatan khatulistiwa di antara 113-30 dan 114-42 Bujur Timur. Daerah ini terletak di jalur lintasan Surabaya-Banyuangi-Bali. Luas wilayah Situbondo yang 1.638,50 Km2 itu hampir keseluruhan terletak di pesisir dengan panjang pantai sekitar 140 Km. sebelah barat Situbondo berbatasan dengan Kabupaten Probolinggo. Batas sebelah utara berbatasan Selat Madura, batas sebelah timur berbatasan dengan Selat Bali. Batas sebelah selatan berbatasan dengan Kabupaten Bondowoso dan pada ujung timur berbatasan dengan Kabupaten Banyuangi (BPS, 2014).

Sengketa tanah di perkebunan Banongan ini meliputi tiga Kecamatan, yaitu Kecamatan Jangkar, Asembagus, dan Banyuputih. Kecamatan Jangkar memiliki luas wilayah $67,00 \mathrm{Km}$, yang terdiri dari 8 Desa dan 44 Dusun. Kecamatan Jangkar ini berpenduduk sebanyak 32.876 jiwa.

Kecamatan Asembagus mempunyai luas wilayah 118,74 Km, yang terbagi dalam 10 Desa dan 36 Dusun dengan kepadatan jumlah penduduk 45.751. Sedangkan Kecamatan Banyuputih luasnya 481,67 Km yang terdiri dari 5 desa (desa Banyuputih, Sumberejo, Sumberanyar, Sumberwaru dan Wonorejo) dengan terdiri dari 27 Dusun dengan jumlah penduduk 48.839 jiwa.

Dari latar geografis di depan, wilayah Banongan didominasi oleh penggunaan tanah pertanian untuk tiga komoditi, yaitu sawah, tebu dan kelapa. Dengan penggunaan sekitar $500 \mathrm{KK}$, hampir seluruh penduduknya terbawa kearus pengerjaan tanah perkebunan. Di luar itu mereka, bekerja sebagai buruh tani dan nelayan. Diskripsi ini menunjukkan kenyataan pola penguasaan tanah dan juga penggunaannya.

Kondisi umum perkebunan di Situbondo berdasarkan data statistik diketahui areal perkebunan di Situbondo cukup luas dan terbesar dan tersebar di seluruh daerah serta terdiri dari berbagai jenis komoditi

32 JURNAL LISAN AL-HAL 
tanaman perkebunan, yang dikelola oleh perkebunan besar negara, perusahaan perkebunan swasta dan perkebunan rakyat.

Menurut data yang ada di kantor cabang perkebunan Situbondo luas perkebunan rakyat yang ada di Kabupaten Situbondo adalah 17.150 Ha, yang ditanami beberapa komoditi. Sedangkan luas areal perkebunan negara tercatat $4.340 \mathrm{Ha}$, yang ditanami tebu, dan kapas. Areal perkebunan besar swasta tercatat seluas 586 Ha yang ditanami tebu, kelapa dan kapuk randu.

Tahapan pengenalan situasi atau persiapan sosial dilakukan di Dusun Bugeman Banyuputih, merupakan kegiatan tindak lanjut dari kegiatan identifikasi atau penjajagan awal. Kegiatan ini dilakukan melalui berbagai pertemuan untuk memperoleh persepsi yang sama. Langkah ini penting untuk mengkomunikasikan tujuan yang ingin dicapai, kegiatan yang perlu dilakukan, dana yang dibutuhkan dan siapa melakukan apa dan lain sebagainya.

\section{Kajian Keadaan Wilayah}

Dalam tahapan kajian wilayah yang paling penting tahap identifikasi. Tahap identifikasi merupakan tahap yang paling kritis dalam suatu daur kegiatan dakwah pemberdayaan. Tahap ini sangat menentukan tahapan berikutnya. Untuk itu, tahap ini perlu dipersiapkan dengan baik dan matang, yang mungkin juga perlu melibatkan tenaga ahli atau pakar untuk melakukannya. Kegiatan identifikasi pengabdian masyarakat bukanlah suatu kegiatan diskret (terpisah) melainkan kegiatan yang berlangsung terus menerus (kontinyu), bukan peristiwa satu kali jadi, melainkan suatu perkembangan adaptif untuk menemukan apa-apa yang baik dikerjakan pada tiap tahapan. Pada tahapan ini, kami melakukan:

Pertama, analisis sosial, ekonomis, teknis, kelembagaan dan analisis lainnya sebagai langkah awal untuk identifikasi permasalahan secara partisipatif yang melibatkan berbagai pihak yang terkena pengaruh maupun yang berpengaruh (stakeholder) baik untuk mengetahui kebutuhan, potensi dan peluang yang ada maupun permasalahan yang ada. Kami melakukan tahapan ini di masjid bersama Jamaah Sholawatan Dusun Bugeman Banyuputih.

Kedua, analisis pihak terkait (stakeholder analysis) untuk menjajagi kepentingan dan pengaruh serta tingkat partisipasi pihak terkait (stakeholder) ini yang dapat dipengaruhi atau mempengaruhi jalannya kegiatan pengabdian masyarakat.

Ketiga, analisis keunggulan komparatif (comparative advantages analysis) untuk menjajagi tingkat kelebihan dan keunggulan suatu 
program tertentu dibandingkan dengan program yang lain sehingga mudah dan laku di pasaran, terutama bagi masyarakat di Dusun Bugeman Banyuputih. Hal ini juga untuk menghindari adanya program yang serupa dan sejenis.

Keempat, appraisal (penilaian). Berdasarkan kegiatan-kegiatan spesifik tersebut di atas langkah selanjutnya adalah melakukan analisis semua hasil yang diperoleh dan melakukan appraisal (kajian mendalam) sehingga diperoleh suatu rumusan yang komprehensif.

Pemilihan Dusun Bugeman Desa Banyuputih Kecamatan Banyuputih Kabupaten Situbondo dalam program pengabdian kepada masyarakat ini, atas beberapa pertimbangan; antara lain:

Pertama, masyarakat Bugeman termasuk masyarakat pesisir yang termarginalkan. Mereka jauh dari akses. Pemukiman penduduk harus melewati hutan belantara dan lahan tebu.

Kedua, penduduk Dusun Bugeman tergolong miskin dan termasuk daerah "rawan". Menurut keterangan dari beberapa masyarakat, pada musim panen atau musim tanam banyak orang luar Dusun Bugeman yang mencari kerja di dusun tersebut. Mereka bekerja selama beberapa bulan di Dusun Bugeman. Tak menutup kemungkinan para pekerja tersebut orang pelarian atau maling.

Ketiga, Dusun Bugeman termasuk Desa Binaan Institut Agama Islam Ibrahimy. Dusun Bugeman termasuk lokasi pengabdian masyarakat para dosen dan mahasisiwa IAI Ibrahimy. Dengan demikian, antara kami dengan masyarakat Bugeman sudah terjalin komunikasi yang baik.

\section{Menyusun Rencana Aksi Partisipatif}

Pada tahapan ini tim merancang kegiatan sesuai dengan problem yang ditemukan dari hasil kajian wilayah bersama-sama dengan warga yang didasarkan atas kebutuhan mereka. Mekanisme ini diterapkan untuk mendorong pembelajaran bersama di antara anggota kelompok yang berkepentingan (multi-stakeholder) dalam program ini. Adapun teknik pelaksanaan langkah kedua ini adalah:

Pertemuan kelompok, sebagai mekanisme untuk merenung, membangun kelompok dan perencanaan bersama. Melalui forum ini, masing-masing pihak didorong untuk mengenali problem yang mereka hadapi dan difasilitasi untuk merumuskan sebuah formula solusi secara bersama-sama. Forum kelompok ini dilakukan dengan mengumpulkan masyarakat untuk mendiskusikan persoalan-persoalan penting kemudian mencari solusi untuk memecahkan masalah. Benchmarking; juga bagian dari mekanisme perenungan, membangun kelompok dan perencanaan

34 JURNAL LISAN AL-HAL 
bersama terhadap beberapa tantangan dan kendala yang ingin dipecahkan secara kolektif. Tentu saja dalam langkah sistem pembelajaran bersama, anggota tim peneliti memiliki kesempatan untuk berpartisipasi aktif dalam forum kegiatan.

\section{Melaksanakan Aksi}

Bentuk kegiatan aksi yang kami lakukan pada kegiatan pengabdian masyarakat yaitu pemberdayaan dalam bidang hukum dan sosial keagamaan. Melaksanakan aksi dalam bidang dalam bidang hukum. Kami melakukan penyadaran kepada masyarakat, agar mereka mendapatkan kembali hak-haknya. Hak-hak tersebut pada ujungnya, akan tercipta kesejahteraan masyarakat. Adapun programnya, antara lain:

Pertama, pertemuan dengan masyarakat. Tujuan kegiatan ini, untuk mendorong terjadinya perubahan terhadap kondisi masyarakat Bugeman, terutama jamaah shalawatan yang lebih baik. Di samping itu untuk melakukan refleksi dan evaluasi tahapan tahun kemarin, tahun sekarang, dan impian tahun depan.

Kedua, identifikasi kasus dan strategi advokasi. Tujuan program ini yaitu untuk mengidentifikasi kasus dan menyusun strategi advokasi selama lima bulan mendatang. Temuan identifikasi, terdapat sebagian petani mulai hampir jenuh terhadap permasalahan tanah HGU, karena advokasi yang dilakukan bertahun-tahun belum sesuai dengan harapan mereka. Adapun hasil dalam program identifikasi kasus, mereview kembali kronologis kasus HGU Bugemen, melakukan pemetaan ulang beberapa kasus dan pemetaan stakecholder. Strateginya, membangun jaringan dengan akar rumput (grassroots), mempererat komunikasi dan lobi-lobi dengan pejabat, DPRD, akademisi \& tokoh masyarakat untuk mengubah kebijakan yang berpihak pada masyarakat, serta membangun opini dan publikasi di media massa.

Ketiga, pengorganisasian petani dan penggalangan sekutu. Tujuan pengorganisasian petani yaitu untuk memperkuat basis dan networking. Sedangkan tujuan penggalangan sekutu untuk melakukakan penyamaan persepsi tentang pentingnya pemberdayaan masyarakat petani penggarap HGU dan memperkuat jaringan agar mendapat dukungan dari beberapa pihak. Hasil pengorganisasian adalah memperkuat basis, terutama dalam jamaah shalawatan dengan melakukan pendidikan politik, pertemuan dilakukan secara intens melalu arisan mingguan, serta penguatan koperasi. Sedangkan hasil penggalangan sekutu adalah menghormati keinginan masyarakat, pentingnya pemberdayaan masyarakat, dan pola kemitraan dengan PTPN yang saling menguntungkan. 
Keempat, yaitu kami melakukan tekanan dan lobi. Pola kerja dalam proses advokasi pada tahapan melakukan tekanan dan lobi. Dan kelima, penyelesaian konflik dengan pembaharuan MoU Berbagai upaya terus dilakukan oleh petani Bugeman untuk memperjuangkan haknya dalam memperoleh hak atas tanah/sertifikat. Akan tetapi usaha tersebut nampaknya tidak menunjukkan hasil yang memuaskan dari targetan yang cita-citakan. Petani kembali harus berpikir realistis atas ketidak mampuan dan kelemahannya dari sumber daya ekonomi dan politik dalam mendukung upaya perjuangannya. Akhirnya petani menjalin kerjasama pola "kemitraan" dengan PTPN XII dengan cara menyewa tanah HGU milik PTPN tersebut untuk dikelola petani.

Adapun aksi dalam bidang spiritual keagamaan, kami melakukan pendekatan dengan pendekatan keagamaan. Sebab pendekatan keagamaan ini akan lebih diterima masyarakat Dusun Bugeman. Tujuan pengabdian masyarakat dalam bidang keagamaan ini agar jamaah shalawatan memiliki pemahaman dan keahlian dalam tajhizul mayyit. Bentuk kegiatan ini adalah pelatihan tajhizul mayyit, yaitu: tatacara merawat dan memandikan jenazah, tatacara menyolati jenazah, dan tatacara mengubur jenazah

Pada kegiatan program pengabdian ini, kami melakukan evaluasi partisipatif yaitu memberi kesempatan bagi tim dan petani Jamaah Sholawatan Penggarap HGU Dusun Bugeman untuk berhenti sejenak dan merefleksikan kegiatan yang telah lalu dengan tujuan untuk membuat keputusan langkah berikutnya. Petani Jamaah Sholawatan Penggarap HGU Dusun Bugeman didorong dan didukung oleh tim untuk memikul tanggung jawab dan kontrol tentang: merencanakan apa yang akan dievaluasi (sasaran dan topik); bagaimana evaluasi akan dilakukan (teknik evaluasi); melaksanakan evaluasi; menganalisis informasi dan menyajikan hasil-hasil evaluasi.

Petani Jamaah Sholawatan Penggarap HGU Dusun Bugeman secara intuitif dan informal mengevaluasi menurut objektif mereka sendiri dan/atau objektif kelompok, karena: kegiatan Petani Jamaah Sholawatan Penggarap HGU Dusun Bugeman sering membutuhkan keterlibatan dan input dari anggota Jamaah Sholawatan. Pada akhirnya merekalah yang memperoleh manfaatnya dan menanggung banyak biaya program. Petani Jamaah Sholawatan Penggarap HGU Dusun Bugeman memilih apakah akan melanjutkan (atau tidak) kegiatan setelah kepergian tim. Jadi, tepat bila tim membantu Petani Jamaah Sholawatan Penggarap HGU Dusun Bugeman untuk melakukan evaluasi yang efektif. Berdasarkan hasil evaluasi, Jamaah Sholawatan dapat memilih untuk melanjutkan kegiatan, 
memodifikasi, mengubah strategi, mengubah objektif, atau menghentikan kegiatan.

Sengketa tanah perkebunan Banongan Situbondo Jawa Timur merupakan sengketa Hak Guna Usaha. Dimana wilayah sengketa tersebut pada jaman Belanda bernama Banongan, maka sengketa ini disebut sebagai sengketa Hak Guna Usaha Banongan. Dalam sengketa ini berhadapan antara petani dan PEMDA Situbondo, serta pemegang Sertifikat Hak Guna Usaha yaitu PTPN XI dan PTPN XII dan PEMDA Situbondo. PD Banongan mewakilkan kepentingan pemegang Hak Guna Usahanya sebagian kepada TNI AL yang dijadikan sebagai areal latihan tempur. PEMDA melindungi aset daerahnya karena Perusahaan Daerah merupakan aset bagi pendapatan daerahnya, yang pengelolaannya didasarkan pada pemberian HGU. Fakta di lapangan menunjukkan bahwa HGU yang dikuasai oleh Perusahaan Daerah Banongan, PTPN XI dan PTPN XII banyak tejadi pelanggaran dan pengingkaran hukum karena itu sudah selayaknya tanah tersebut dikembalikan pada rakyat sesuai dengan amanat UUPA 1960.

Konflik agraria yang terjadi di Banongan hanya bagian dari potret sengketa agraria yang terjadi. Kasus ini bisa dilihat bahwa konflik antara rakyat tani dengan pihak lain yang dalam hal ini bukan bagian dari kelas petani khususnya dalam memperebutkan tanah untuk kegiatan mereka masing-masing terjadi dengan sangat keras. Rakyat membutuhkan tanahtanah untuk sumber kehidupan dan kelanjutan hidup mereka. Sedang pihak lain pada umumnya memerlukan tanah tersebut untuk kegiatan usaha ekonomi mereka dengan skala besar. Meskipun demikian persengketaan yang terjadi diantara kedua pihak ini tidak bisa dikatakan diakibatkan oleh langkanya sumber agraria (termasuk tanah), tetapi lebih diakibatkan oleh ekspansi modal secara besar-besaran yang kemudian berhadapan dengan kepentingan ekonomi (subsisten) maupun kultural rakyat kebanyakan. Dalam kontek pengembangan usaha ekonomi skala besar itu dan kemudian tanah-tanah garapan petani atau tanah-tanah milik masyarakat adat diambil alih oleh para pengusaha melalui fasilitasfasilitas pengalihan hak atas sumber-sumber agraria yang disediadakan oleh negara.

Pendekatan (approaches) yang digunakan dalam suatu upaya penyelesaian sengketa sangatlah penting, sebab upaya ini yang nantinya yang akan menentukan hasil seperti apa yang akan diperoleh dari suatu pendekatan. Pendekatan dalam penyelesaian sengketa dapat dibagi ke dalam tiga pendekatan, yaitu; Pendekatan dengan cara penggunaan kekuatan (power based). Pendekatan dengan cara "benar-salah" 
(pendekatan hukum/right based), dan pendekatan dengan cara penggalian kepentingan dan kebutuhan pihak-pihak yang bersengketa (inters based). Pendekatan berdasarkan kepentingan adalah pendekatan penyelesaian sengketa dimana kepentingan serta kebutuhan para pihak digali secara bersama untuk kemudian dibangaun kesepakatan (solusi) yang mempu mencerminkan kebutuhan serta kepentingan pihak-pihak yang bersengketa secara seimbang (mutually shared interest). Pendekatan penyelesaian sengketa ini ditujukan untuk mencapai suatu solusi/kesepakatan yang sifatnya "menang-menang". Pendekatan penyelesaian sengketa ini berdasarkan kepentingan yang dapat dilakukan melalui mekanisme perundingan (negosiasi) maupun penengahan (mediasi).

Penguatan kelembagaan organisasi petani (OT) merupakan suatu hal mutlak yang harus dilakukan untuk dapat mengimbangi kekutan yang dimiliki oleh pihak lawan dalam suatu proses penyelesaian sengketa. serta perlunya peran lembaga-lembaga pemerintahan (terutama DPR dan BPN) dalam mendukung terjadinya proses landreform di desa, seperti yang terjadi pada sengketa tanah perkebunan di Blitar. Pihak-pihak terkait kemudian mendorong ke dalam kerangka srategi landreform yang berpijak pada Reforma Tata Kuasa, Tata Guna dan Tata Produksi.

Refleksi tentang pelatihan tajhizul mayyit, antara lain: Pertama, masyarakat berharap agar materi tajhizul mayyit dengan materi yang lain, disampaikan pada kegiatan Jamaah Shalawatan. Kedua, beberapa penonton film tersebut mendapatkan informasi baru dan pemahaman yang lebih komprehensif tentang tajhiz al-mayyit. Sebab kalau melalui media film mereka langsung tahu praktiknya dan bisa dipahami, lain kalau hanya membaca di kitab-kitab. Ketiga, film drama tajhiz al-mayyit ini amat membantu para Jamaah Sholawatan yang mengajar bidang studi fiqh. Film ini sebagai media pembelajaran yang amat membantu mereka dalam mengajar fiqh, terutama bab jenazah. Ketiga, film tersebut mendapat respon yang amat positif dari penonton. Mereka berharap agar Fakultas Dakwah mengembangkan media pembelajaran tersebut sebagai media dakwah yang amat efektif.

\section{Simpulan}

Fokus pemberdayaan dalam program ini adalah penguatan masyarakat untuk memperoleh kembali kuasa kelola (power of management system), kuasa milik (power of ownership system), dan kuasa manfaat (power of unility system) yang hilang. Ada dua bidang yang kami lakukan, yang saling berkaitan. Pertama, dalam bidang hukum. Kami

38 JURNAL LISAN AL-HAL 
melakukan penyadaran kepada masyarakat, agar mereka mendapatkan kembali hak-haknya. Hak-hak tersebut pada ujungnya, akan tercipta kesejahteraan masyarakat. Kedua, dalam bidang spiritual. Kami melakukan pendekatan dengan pendekatan keagamaan. Sebab pendekatan keagamaan ini akan lebih diterima masyarakat Dusun Bugeman.

Cara penyelesaian sengketa dalam pengabdian masyarakat ini diarahkan pada kerjasama untuk mencapai kompromi, serta masingmasing pihak tidak perlu berambisi untuk mempertahankan fakta dan bukti yang mereka miliki, serta tidak dilakukan dengan tindakan kekerasan (anti violance). Di samping itu faktor penghambat lain dalam penerapan yang efektif yang cukup signifikan adalah ketidak seimbangan kekuatan diantara para pihak yang bersengketa, sehingga yang terjadi adalah salah satu pihak yang berada dalam posisi yang lemah dan pihak yang lain dalam posisi yang kuat. Seharusnya pihak petani dan pihak pemegang HGU sama-sama dalam posisi tawar yang seimbang agar kondisi saling tergantung.

Lemahnya posisi tawar kelompok petani sangatlah berpengaruh terhadap kondisi perundingan yang ada. Oleh karena itu mutlak perlu dilakukan penguatan organisasi rakyat (organization framework assessment) dengan tujuan menyeimbangkan kekuatan dalam membuat tawaran-tawaran penyelesaian sengketa (bargaining power). Sehingga juga dalam proses penyelesaian sengketa tersebut masing-masing pihak merasa terikat untuk melaksakan kesaepakatan yang telah dicapai dengan konsisten.

Secara garis besar, pada tahapan advokasi ini, kami melakukan beberapa tahapan, antara lain: pertemuan dengan masyarakat, identifikasi dan strategi advokasi, pengorganisasian petani dan penggalangan sekutu, tekanan dan lobi; serta penyelesaian konflik. Aksi bersama masyarakat tersebut tujuannya agar masyarakat memperoleh kembali power of management, power of ownership dan power of unility system berdasarkan nilai-nilai keagamaan.

Aksi dalam bidang spiritual keagamaan. Kami akan melakukan pendekatan dengan pendekatan keagamaan. Sebab pendekatan keagamaan ini akan lebih diterima masyarakat Dusun Bugeman. Tujuan pengabdian masyarakat dalam bidang keagamaan ini agar jamaah shalawatan memiliki pemahaman dan keahlian dalam tajhizul mayyit. Bentuk kegiatan ini adalah pelatihan tajhizul mayyit, yaitu: tatacara merawat dan memandikan jenazah; tatacara menyolati jenazah; dan tatacara mengubur jenazah 
Adapun beberapa saran dan rekomendasi dari hasil kegiatan pengabdian masyarakat berbasis pendampingan ini, antara lain: Pertama, PTPN XII harus tetap menjalin komunikasi dengan masyarakat untuk memperpanjang MoU kemitraan. Kedua, IAI Ibrahimy harus terus mendampingi masyarakat, terutama Jamaah Sholawatan dalam menghadapi perpanjangan MoU kemitraan Ketiga, bagi petani penggarap HGU terutama Jamaah Sholawatan agar berperan aktif dalam program kemitraan dan selalu menjalin komunikasi dengan berbagai pihak, terutama mitra yang melakukan pemberdayaan selama ini.

\section{DAFTAR PUSTAKA}

A. Halim, Paradigma Dakwah Pengembangan Masyarakat, dalam Moh Ali Aziz (ed), Dakwah Pemberdayaan Masyarakat Paradigma Aksi Metodologi, Yogyakarta, LKiS. 2005.

Al Araf dan Puryadi, Awan., Perebutan Kuasa Tanah. LAPPERA Pustaka Utama. 2002.

R. Wolf, Eric., Perang Petani. . Yokyakarta: Insist Press. 2004.

Zada, Khamami, Dakwah Transformatif: Mengantar Dai sebagai Pendamping Masyarakat, www.nu.or.id , 2006.

Mubyarto dkk., Tanah dan Tenaga Kerja Perkebunan (Kajian Social Ekonomi). Yokyakarta: Aditya Media. 1992.

Mulyo. H,. Studi Tentang Makanisme Alternatif Penyelesaian Sengketa (MAPS). Jakarta: ELSAM, 1996.

Sugianto., Mekanisme Alternatif Penyelesaian Sengketa (MAPS) Dalam Sengketa Pertanahan (Suatu Pemikiran Awal Tentang Kelayakan Pengembangan MAPS Pertanahan). DIKLAT SEMA Fakultas Hukum Brawijaya Malang bekerja sama dengan Lembaga Bantuan Hukum (LBH), Surabaya, 1996.

Sukardi, Implementasi Metodologi RRA dan PRA untuk Merancang Perubahan Berencana, dalam Moh Ali Aziz (ed), Dakwah Pemberdayaan Masyarakat Paradigma Aksi Metodologi, Yogyakarta, LkiS, 2005.

Wijoyo, Suparto, Penyelesaian Sengketa Lingkungan (Settlement of Environmental Dispute). Surabaya: Airlangga University Press, 1999.

Tim KPA. Pembaharuan Agraria Adalah Agenda Yang Inklusif Dengan Reformasi Sosial Secara Menyeluruh. Bandung: KPA, 1998.

Hafidz, Wardah dan Budiharga, Wiladi, Model Pemberdayaan Rakyat Berkeadilan Gender, dalam Panduan Pendidikan Politik Bagi

$40 \quad$ JURNAL LISAN AL-HAL 
Perempuan, Komite Perempuan Pro Demokrasi, Unair Surabaya, 1999.

Wijardjo, B. dan Perdana, Herlambang, Rekleiming dan Kedaulatan Rakyat. Jakarta: YLBHI-RACA Institute, 2001.

Wijardjo. B, Tanpa Tahun. RUU Perkebunan : Melestarikan Eksploitasi dan Ketergantungan. RACA Institute.

Wiradi. G. Reforma Agraria Perjalanan Yang Belum Berakhir. Yogyakarta: Insist, KPA dan Pustaka Pelajar. 2000. 
"Pemberdayaan Masyarakat"

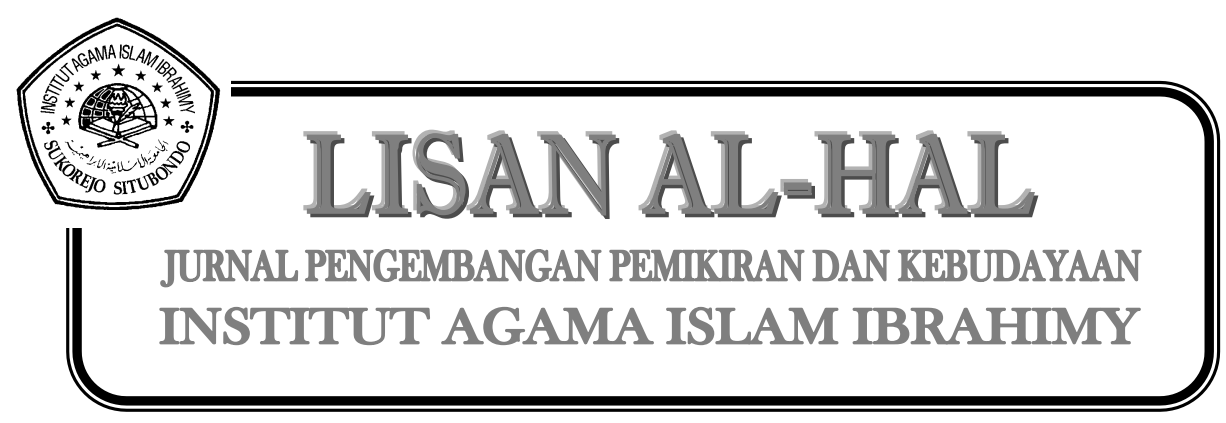

$42 \mid$ JURNAL LISAN AL-HAL 